\title{
Skrining dan Identifikasi Bakteri Laut Penghasil Enzim Selulase yang Berasosiasi dengan Spons
}

\section{(Screening and Identification of Marine Sponge-Associated Bacteria Producing Cellulase Enzyme)}

\author{
Rika Indri Astuti, Yohanes Bernadino Putera Saju, Dina Aribah, Aris Tri Wahyudi*
}

(Diterima Juli 2021/Disetujui Januari 2022)

\begin{abstract}
ABSTRAK
Bakteri laut yang berasosiasi dengan spons dapat berpotensi sebagai sumber enzim baru, terutama selulase yang dapat dimanfaatkan untuk berbagai industri. Penelitian ini bertujuan menskrining dan mengidentifikasi secara molekuler bakteri penghasil enzim selulase yang berasosiasi dengan spons. Sebanyak 38 isolat bakteri berhasil diisolasi dari spons Aaptos sp., Euryspongia sp., dan Haliclona sp dengan metode cawan sebar. Sebanyak 14 isolat $(37 \%)$ dari 38 isolat bakteri yang berasosiasi dengan spons menunjukkan aktivitas selulolitik secara kualitatif pada medium carboxy methyl cellulose (CMC), dengan indeks selulolitik berkisar antara 0.31 hingga 1.63. Aktivitas selulolitik dari tiga isolat yang menunjukkan indeks selulolitik tertinggi adalah isolat bakteri dengan kode Y.5.10, Y.5.11, dan Y.40.6. Isolat Y.5.10, Y.5.11, dan Y.40.6 menunjukkan aktivitas enzim selulase secara kuantitatif berturutturut sebesar $0.0053 \mathrm{U} / \mathrm{mL} ; 0.0083 \mathrm{U} / \mathrm{mL}$; dan $0.0124 \mathrm{U} / \mathrm{mL}$. Aktivitas spesifik selulase tertinggi ditunjukkan oleh isolat Y.40.6 dengan nilai $0.3391 \mathrm{U} / \mathrm{mg}$. Hasil identifikasi bakteri berdasarkan sekuens gen 16S rRNA menunjukkan bahwa isolat Y.5.10, Y.5.11, dan Y.40.6, secara berturut-turut memiliki kemiripan yang tinggi (kemiripan $\geq 99 \%)$ dengan Bacillus sp., B. subtilis, dan B. cereus.
\end{abstract}

Kata kunci: bakteri asosiasi spons, isolasi, selulase, 16S rRNA

\section{ABSTRACT}

Marine bacteria associated with sponges can be used as a source of new enzymes, especially cellulase which are potentially used for various industries. The aim of this study was to screen and identify the cellulolytic bacteria associated with sponges. A total of 38 isolates have been successfully isolated from sponges Aaptos sp., Euryspongia sp., and Haliclona sp. by a spread plate method. Amongst 38 isolates, 14 (37\%) showed cellulolytic activities in carboxy methyl cellulose (CMC) medium with a cellulolytic index ranging from 0.31 to 1.63 . The three highest cellulolytic index was exhibited by bacterial isolates coded Y.5.10, Y.5.11, and Y.40.6. Isolates Y.5.10, Y.5.11, and Y.40.6 showed cellulolytic activity of $0.0053 \mathrm{U} / \mathrm{mL} ; 0.0083 \mathrm{U} / \mathrm{mL}$; and $0.0124 \mathrm{U} / \mathrm{mL}$, respectively, as were tested by spectrophotometry. The highest specific enzymatic activity was showed by isolate Y.40.6 with a value of 0.3391 U/mg. Based on 16S rRNA gene, isolate Y.5.10, Y.5.11, and Y.40.6 were highly similar to (similarity $\geq 99 \%$ ) Bacillus sp., B. subtilis, and B. cereus, respectively.

Keywords: cellulase, isolation, sponge-associated bacteria, 16S rRNA

\section{PENDAHULUAN}

Spons merupakan hewan laut yang tergolong ke dalam filum Porifera. Spons bersifat sessile dan cara memperoleh nutrisinya adalah melalui proses penyaringan (Lavrov \& Kosevich 2014). Pada proses penyaringan partikel nutrisi, mikroorganisme laut akan ikut tersaring dan berasosiasi dengan spons. Komunitas mikroorganisme yang berasosiasi dengan spons sangat beragam dan sebagian besar memiliki inang spons yang spesifik (Webster \& Taylor 2012). Jumlah mikroorganisme yang berasosiasi dengan spons dapat mencapai $60 \%$ dari total biomassa spons (Thomas et

Departemen Biologi, Fakultas Matematika dan IImu Pengetahuan Alam, Institut Pertanian Bogor, Kampus IPB Darmaga, Bogor 16680

* Penulis Korespondensi: Email: ariswa@apps.ipb.ac.id al. 2010) atau $10^{9} \mathrm{sel} / \mathrm{cm}^{3}$ jaringan spons (Webster \& Thomas 2016). Simbiosis antara spons laut dan mikroorganisme sangat menarik untuk dipelajari lebih lanjut karena mikroorganisme dapat melakukan interaksi secara biokimia maupun genetika dengan inangnya dalam hal sintesis berbagai enzim dan senyawa bioaktif potensial. Hasil interaksi tersebut dibuktikan melalui banyak laporan penemuan enzim maupun senyawa bioaktif potensial baru yang berasal dari mikroorganisme yang berasosiasi dengan spons.

Penelitian terdahulu telah banyak melaporkan beberapa potensi mikroorganisme yang berasosiasi dengan spons pada berbagai bidang. Penelitian Wahyudi et al. (2010) melaporkan bahwa bakteri yang berasosiasi dengan spons Jaspis sp. dapat menghambat protease yang dihasilkan oleh bakteri patogen. Safari et al. (2016) juga melaporkan bahwa senyawa antibakteri dan antikanker dapat dihasilkan 
oleh bakteri yang berasosiasi dengan spons Haliclona sp. Selain itu, Rini et al. (2017) melaporkan bahwa senyawa antivibriosis dapat dihasilkan oleh bakteri yang berasosiasi dengan spons Aaptos sp. dan Hyrtios sp. Senyawa antioksidan, antiglikasi, dan antiaging juga dapat dihasilkan oleh bakteri yang berasosiasi dengan spons Haliclona sp. dan Petrosia sp. (Prastya et al. 2019). Selain senyawa bioaktif, enzim selulase dan laktase juga ditemukan pada beberapa bakteri yang berasosi dengan spons di antaranya Crella sp., Agelas sp., Callyspongia sp., Hyrtios sp., dan Spongia sp. yang berasal dari Kepulauan Seribu, Indonesia (Maharsiwi et al. 2020).

Berdasarkan berbagai potensi yang telah diketahui, laporan mengenai bakteri penghasil enzim selulase yang berasosiasi dengan spons laut masih sedikit dilakukan. Sementara itu, kini enzim selulase sangat banyak dimanfaatkan pada berbagai bidang industri, seperti industri kertas, tekstil, dan makanan (Kuhad et al. 2011). Enzim yang memiliki sifat toleran yang tinggi terhadap tekanan osmosis, $\mathrm{pH}$, atau suhu dapat menentukan keberhasilan aplikasi di industri. Dengan demikian, eksplorasi enzim dengan sifat toleran yang tinggi menjadi hal yang perlu diperhatikan, dan sifat toleran tersebut bisa didapatkan melalui lingkungan yang ekstrem, salah satunya adalah mikroorganisme yang berasosiasi dengan spons laut. Oleh karena itu, penelitian ini bertujuan untuk menskrining dan mengidentifikasi secara molekuler bakteri penghasil enzim selulase yang berasosiasi dengan spons.

\section{METODE PENELITIAN}

\section{Isolasi Bakteri Laut yang Berasosiasi dengan Spons}

Isolasi bakteri laut yang berasal dari spons dilakukan dengan teknik pengenceran dan cawan sebar. Tiga spesies spons yang digunakan ialah Aaptos sp., Euryspongia sp., dan Haliclona sp.. Permukaan spons dibilas sebanyak tiga kali dengan air laut steril. Kemudian, sampel spons ditimbang sebanyak $1 \mathrm{~g}$ dan dihaluskan dengan mortar steril. Hasil gerusan dilarutkan dalam garam fisiologis $\mathrm{NaCl}$ $0,85 \%(\mathrm{w} / \mathrm{v})$ dan dilakukan pengenceran secara serial sebesar $10^{-1}$ dan $10^{-2}$. Sebanyak $0.1 \mathrm{~mL}$ sediaan pada setiap pengenceran disebar secara duplo pada tiga media cawan, yaitu Nutrient Agar (NA: $\mathrm{NaCl} 25 \mathrm{~g}$, bakto-pepton $10 \mathrm{~g}$, ekstrak khamir $5 \mathrm{~g}$, agar $20 \mathrm{~g}$, akuades $1 \mathrm{~L}$ ), Sea Water Complete Agar (SWC: ekstrak khamir $1 \mathrm{~g}$, gliserol $3 \mathrm{~mL}$, bakto-pepton $5 \mathrm{~g}$, air distilasi $250 \mathrm{~mL}$, air laut $750 \mathrm{~mL}$, dan agar $15 \mathrm{~g}$ ), dan Zobell Marine Agar (ZMA: pepton 5 g, ekstrak khamir 1 $\mathrm{g}$, ferric citrate $0,1 \mathrm{~g}$, sodium chloride 19,45 g, magnesium chloride $8,8 \mathrm{~g}$, sodium sulphate $3,24 \mathrm{~g}$, calcium chloride $1,8 \mathrm{~g}$, potassium chloride 0,55 g, sodium bicarbonate $0,16 \mathrm{~g}$, potassium bromide $0,08 \mathrm{~g}$, strontium chloride $0,034 \mathrm{~g}$, boric acid $0,022 \mathrm{~g}$, sodium silicate $0,004 \mathrm{~g}$, sodium fluorate $0,0024 \mathrm{~g}$, ammonium nitrate $0,0016 \mathrm{~g}$, disodium phosphate $0,008 \mathrm{~g}$, agar 15 g, dan akuades 1 L). Kemudian, sediaan diinkubasi pada suhu ruang $\left( \pm 27^{\circ} \mathrm{C}\right)$ selama 72 jam hingga muncul koloni-koloni bakteri yang dapat terlihat dengan jelas. Koloni bakteri tunggal yang tumbuh dengan karakter morfologi yang berbeda (bentuk, tepian, ukuran, elevasi, warna, karakteristik optik, dan permukaan) dipilih untuk dimurnikan.

\section{Skrining Bakteri Penghasil Enzim Selulase}

Skrining enzim selulase dilakukan secara kualitatif melalui uji zona bening pada isolat bakteri di media carboxymethyl-cellulose (CMC $10 \mathrm{~g}, \mathrm{MgSO}_{4} . \mathrm{H}_{2} \mathrm{O} 0,2 \mathrm{~g}$, $\mathrm{KNO}_{3} 0,75 \mathrm{~g}, \mathrm{~K}_{2} \mathrm{HPO}_{4} 0,5 \mathrm{~g}, \mathrm{FeSO}_{4} . \mathrm{H}_{2} \mathrm{O}$ 0,02 g, $\mathrm{CaCl}_{2}$ 0,04 g, bakto-pepton $2 \mathrm{~g}$, agar $15 \mathrm{~g}$, dan akuades $1 \mathrm{~L}$ ). Inkubasi dilakukan pada suhu ruang $\left( \pm 27^{\circ} \mathrm{C}\right)$ selama 48 jam. Medium yang telah ditumbuhi koloni bakteri selanjutnya digenangi pewarna congo red $1 \%$ selama 15 menit dan dibilas dengan larutan $\mathrm{NaCl} 2 \mathrm{M}$. Indeks aktivitas enzim selulase ditentukan berdasarkan zona bening yang terbentuk di sekitar koloni bakteri dengan rumus:

Indeks selulolitik $=\frac{\text { diameter zona bening }(\mathrm{mm})-\text { diameter koloni }(\mathrm{mm})}{\text { diameter } \text { koloni }(\mathrm{mm})}$

\section{Penentuan Aktivitas dan Aktivitas Spesifik Enzim Selulase Bakteri Potensial}

Aktivitas dan aktivitas spesifik enzim selulase ditentukan dengan menggunakan metode 3,5Dinitrosalicylic acid (DNS) (Miller 1959). Tiga isolat bakteri selulolitik terbaik diinokulasikan pada medium CMC cair dan diinkubasi pada suhu ruang $\left( \pm 27^{\circ} \mathrm{C}\right)$ dengan agitasi $120 \mathrm{rpm}$ selama 24 jam. Kultur sebanyak $1,5 \mathrm{~mL}$ disentrifugasi dengan kecepatan $9400 \mathrm{rpm}$ selama 10 menit pada suhu $4^{\circ} \mathrm{C}$ dan hasil supernatan dipisahkan sebagai enzim ekstrak kasar (EEK). Aktivitas enzim diukur dengan komposisi $0,5 \mathrm{~mL}$ EEK dan $0,5 \mathrm{~mL}$ substrat CMC $1 \%$ dalam buffer fosfat $0,5 \mathrm{M} \mathrm{pH} 7$ setelah inkubasi pada suhu ruang $\left( \pm 27^{\circ} \mathrm{C}\right)$ selama 30 menit. Kemudian, reaksi dihentikan melalui penambahan $1 \mathrm{~mL}$ DNS 1\% dan pemanasan selama 10 menit. Kadar gula pereduksi dan konsentrasi protein ditentukan berdasarkan nilai absorbansi menggunakan spektrofotometer pada panjang gelombang $540 \mathrm{~nm}$ dan $595 \mathrm{~nm}$. Kurva standar glukosa dan bovine serum albumin (BSA) dibuat terlebih dahulu sebagai acuan perhitungan kadar gula pereduksi dan konsentrasi protein (Bradford 1976). Aktivitas enzim selulase sebanyak satu unit didefinisikan sebagai jumlah enzim yang dibutuhkan untuk melepas $1 \mu \mathrm{mol}$ glukosa dalam waktu 1 menit. Sementara itu, aktivitas spesifik enzim didefinisikan sebagai jumlah protein yang dibutuhkan dalam setiap aktivitas enzim.

\section{Identifikasi Isolat Bakteri Potensial Berdasarkan Gen $16 S$ rRNA}

Tiga isolat bakteri selulolitik terbaik dikulturkan pada medium luria-bertani broth (LB: $\mathrm{NaCl} 25 \mathrm{~g}$, tripton $10 \mathrm{~g}$, ekstrak khamir $5 \mathrm{~g}$, dan akuades $1 \mathrm{~L}$ ) dan diinkubasi pada suhu ruang $\left( \pm 27^{\circ} \mathrm{C}\right)$ dengan agitasi $120 \mathrm{rpm}$ selama 18 jam. Kultur disentrifugasi dengan kecepatan 
12.000 rpm selama 1 menit, dan supernatan dipindahkan. DNA genom bakteri diisolasi menggunakan protokol mini gDNA Bacteria Kit Geneaid (Taiwan). Amplifikasi gen 16S rRNA dilakukan dengan primer 63F (5'-CAG GCC TAA CAC ATG CAA GTC-3') dan primer 1387R (5'-GGG CGG WGT GTA CAA GGC-3') (Marchesi et al. 1998) dengan target pita berukuran $1.300 \mathrm{pb}$. Komposisi PCR mix terdiri atas $25 \mu \mathrm{L}$ GoTaq Green Mastermix 2×, $5 \mu \mathrm{L}$ primer $1387 \mathrm{R}$ (10 pmol), $5 \mu \mathrm{L}$ primer $63 \mathrm{~F}(10 \mathrm{pmol}), 4$ $\mu \mathrm{L}$ sampel DNA (100 $\mathrm{ng} / \mu \mathrm{L})$, dan $11 \mu \mathrm{L}$ nuclease free water. Kondisi PCR yang digunakan ialah predenaturasi $\left(94^{\circ} \mathrm{C} 5\right.$ menit), 35 siklus untuk denaturasi $\left(94^{\circ} \mathrm{C} 30\right.$ detik), annealing $\left(55^{\circ} \mathrm{C} 45\right.$ detik), dan elongasi $\left(72^{\circ} \mathrm{C} 1\right.$ menit 30 detik), kemudian PCR diakhiri dengan post-elongasi $\left(72^{\circ} \mathrm{C} 10\right.$ menit) dan post-PCR $\left(4^{\circ} \mathrm{C} 5\right.$ menit). Amplikon target selanjutnya dikirim ke perusahaan jasa $1^{\text {st }}$ Base, Malaysia untuk dilakukan pembacaan sekuens. Hasil sekuens DNA gen target diolah menggunakan perangkat lunak Seqtrace 0.9.0 lalu disejajarkan dengan database pada National Center for Biotechnology Information (NCBI [https://ncbi.nlm.nih.gov]) melalui program Basic Local Alignment Search Tool Nucleotide (BLASTN). Pembuatan pohon filogenetik dilakukan dengan menggunakan perangkat lunak Molecular Evolutionary Genetics Analysis (MEGA) 10.0 dengan metode neighbor-joining dan nilai bootstrap 1000 kali.

\section{HASIL DAN PEMBAHASAN}

\section{Isolat Bakteri yang Berasosiasi dengan Spons}

Sebanyak 38 isolat bakteri dengan morfologi yang berbeda berhasil diisolasi dari 3 jenis spons, yaitu
Aaptos sp., Haliclona sp., dan Euryspongia sp. pada 3 jenis medium, yaitu NA, ZMA, dan SWC. Spons Haliclona sp. memiliki jumlah sel bakteri paling banyak, yaitu $1,5 \times 10^{7} \mathrm{CFU} / \mathrm{g}$, sementara Aaptos sp. memiliki keragaman bakteri paling tinggi, yaitu 21 jenis bakteri (Tabel 1). Jumlah tersebut masih belum bisa mewakili total populasi bakteri yang berasosiasi dengan spons karena hanya $1 \%$ bakteri yang mampu dikulturkan dalam kondisi laboratorium, dan 99\% lainnya bersifat unculturable (Vartoukian et al. 2010). Perbedaan lingkungan dan nutrisi pada setiap spons mengakibatkan adanya perbedaan komunitas dan jumlah bakteri yang bersimbiosis (Santos-Gandelman et al. 2014). Total isolat bakteri yang berhasil diisolasi pada medium SWC (22 isolat) lebih tinggi dibanding pada medium ZMA (8 isolat) dan NA (8 isolat) (Tabel 1). Medium SWC memiliki komposisi mineral dan nutrisi lainnya yang mirip dengan habitat asli, yaitu air laut. Dengan demikian, medium SWC lebih mendukung pertumbuhan bakteri laut dibandingkan dengan medium ZMA dan NA.

\section{Skrining Bakteri Penghasil Enzim Selulase}

Skrining bakteri menghasilkan 14 isolat (37\%) dari total 38 isolat yang dapat memproduksi selulase. Hal ini ditandai dengan adanya zona bening di sekitar koloni bakteri setelah ditetesi congo red (Gambar 1). Bakteri yang menghasilkan enzim selulase dapat mengubah selulosa pada medium CMC menjadi monosakarida atau disakarida sehingga ketika CMC ditetesi congo red lalu dibilas, selulosa berwarna merah, sedangkan monosakarida dan disakarida pada sekeliling koloni tidak terwarnai (Gohel et al. 2014). Indeks selulolitik bakteri berkisar antara 0,31 hingga 1,63. Isolat Y.5.10, Y.5.11, dan Y.40.6 merupakan tiga

Tabel 1 Total bakteri yang berhasil diisolasi dari spons laut

\begin{tabular}{|c|c|c|c|c|c|}
\hline \multirow{2}{*}{ Jenis spons } & \multicolumn{3}{|c|}{ Jumlah bakteri dalam tiap gram spons } & \multirow{2}{*}{ Total bakteri } & \multirow{2}{*}{ Sel bakteri (CFU/g) } \\
\hline & SWC & ZMA & NA & & \\
\hline Aaptos sp. & 13 & 5 & 3 & 21 & $4,5 \times 10^{6}$ \\
\hline Haliclona sp. & 4 & 3 & 2 & 9 & $1,5 \times 10^{7}$ \\
\hline Euryspongia sp. & 5 & 0 & 3 & 8 & $8,7 \times 10^{6}$ \\
\hline \multicolumn{4}{|c|}{ Total } & 38 & $2,8 \times 10^{7}$ \\
\hline
\end{tabular}

Keterangan:SWC (sea-water complete); ZMA (zobell marine agar); NA (nutrient agar); CFU (colony forming unit, satuan untuk menyatakan jumlah sel bakteri); CFU/g (jumlah sel bakteri dalam tiap gram spons).
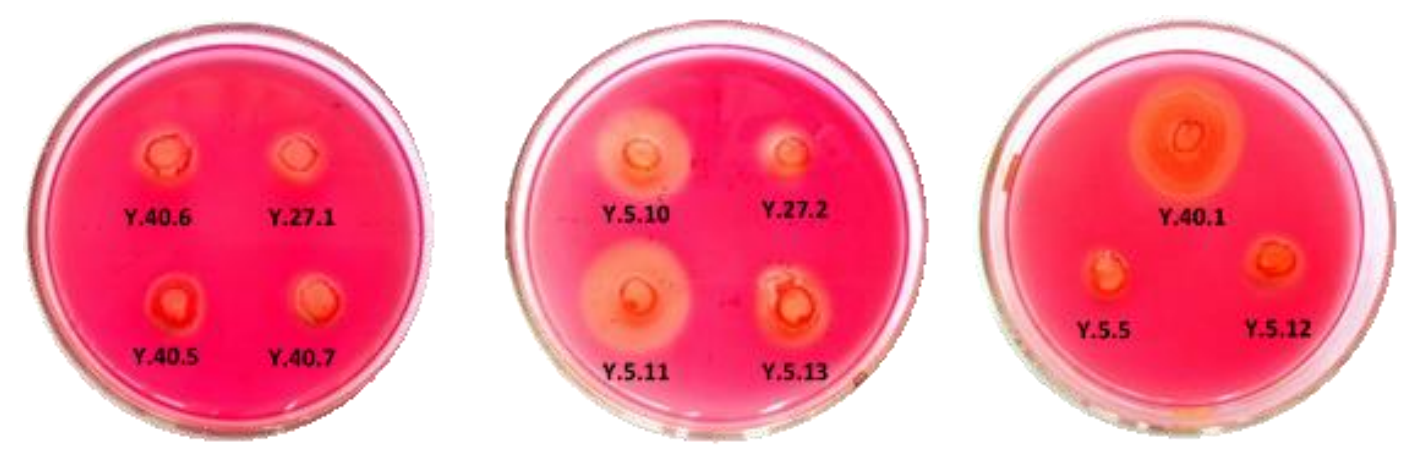

Gambar 1 Aktivitas selulolitik bakteri yang diisolasi dari spons pada medium CMC setelah inkubasi 48 jam pada suhu ruang $\left( \pm 27^{\circ} \mathrm{C}\right)$ 
isolat bakteri dengan indeks selulolitik terbaik, yang secara berturut-turut adalah 1,58; 1,63; dan 0,80 (Tabel 2).

\section{Aktivitas Enzim Selulase pada Bakteri yang Berasosiasi dengan Spons}

Hasil uji aktivitas enzim secara kualitatif menggunakan supernatan menunjukkan bahwa Isolat Y.5.10, Y.5.11, dan Y.40.6 memiliki aktivitas enzim dan aktivitas spesifik enzim yang berbeda. Aktivitas enzim dan aktivitas spesifik enzim tertinggi ditunjukkan oleh isolat Y.40.6, yaitu $0,0124 \mathrm{U} / \mathrm{mL}$ dan $0.3391 \mathrm{U} / \mathrm{mg}$ (Tabel 3), akan tetapi nilai tersebut masih tergolong rendah. Gaur \& Tiwari (2015) melaporkan bahwa aktivitas enzim ekstrak kasar dari bakteri dapat mencapai 3.788 Unit. Selulase menghidrolisis selulosa secara bertahap, yaitu dengan cara memotong rantai panjang selulosa menjadi oligosakarida maupun disakarida oleh endoglukanase dan selobiohidrolase, kemudian mengubahnya menjadi monomer-monomer glukosa oleh $\beta$-glukosidase (Ali et al. 2014). Kerja enzim selulase yang tidak optimal akan menghasilkan glukosa, disakarida, atau oligosakarida dengan kadar yang rendah. DNS hanya berikatan dengan gula pereduksi seperti glukosa, disakarida, dan oligosakarida yang memiliki ikatan $\mathrm{OH}$ pada ujungnya. Jika selulase bekerja kurang efektif, absorbansi yang terbaca pada panjang gelombang $540 \mathrm{~nm}$ akan rendah. Berdasarkan hal tersebut, enzim selulase yang dihasilkan isolat Y.5.10, Y.5.11, dan Y.40.6 dimungkinkan belum bekerja secara optimal akibat $\mathrm{pH}$ dan suhu yang belum optimal. Meskipun demikian, enzim yang berasal dari lingkungan ekstrem, seperti air laut memiliki karakter yang unik, salah satunya adalah salttolerant thermostable (dos Santos et al. 2018). Dengan demikian, eksplorasi enzim potensial baru dari lingkungan perairan Indonesia penting untuk dilakukan.

\section{Identifikasi Tiga Isolat Bakteri Selulolitik Potensial}

Hasil amplifikasi gen 16S rRNA dari isolat Y.5.10, Y.5.11, dan Y.40.6 menghasilkan pita target berukuran 1.3 kb (Gambar 2). Hasil identifikasi berdasarkan

Tabel 2 Indeks selulolitik pada bakteri yang diisolasi dari spons

\begin{tabular}{lcc}
\hline Spons & Kode isolat & $\begin{array}{c}\text { Indeks selulolitik } \pm \\
\text { standar deviasi }\end{array}$ \\
\hline Aaptos sp. & Y.5.5 & $0,35 \pm 0,15$ \\
& Y.5.10 & $1,58 \pm 0,08$ \\
& Y.5.11 & $1,63 \pm 0,13$ \\
& Y.5.12 & $0,63 \pm 0,13$ \\
& Y.5.13 & $0,46 \pm 0,04$ \\
& Y.5.14 & $0,50 \pm 0,00$ \\
& Y.5.16 & $0,74 \pm 0,64$ \\
& Y.5.18 & $0,45 \pm 0,05$ \\
\hline Haliclona sp. & Y.27.1 & $0,50 \pm 0,00$ \\
& Y.27.2 & $0,67 \pm 0,33$ \\
\hline suryspongia & Y.40.1 & $0,31 \pm 0,02$ \\
& Y.40.5 & $0,38 \pm 0,13$ \\
& Y.40.6 & $0,80 \pm 0,20$ \\
& Y.40.7 & $0,76 \pm 0,49$ \\
\hline
\end{tabular}

sekuens gen 16S rRNA menunjukkan isolat Y.5.10, Y.5.11, dan Y.40.6 secara berturut-turut memiliki kemiripan dengan Bacillus sp. GNTEW-13-1, B. subtilis BAB-7051, dan B. cereus 45-5 (Tabel 4). Persentase kemiripan yang dimiliki oleh tiga isolat tersebut lebih dari $99 \%$ dengan E-value (expect value) bernilai 0 . Isolat Y.5.10, Y.5.11, dan Y.40.6 konsisten berada dalam cluster yang berdekatan dengan spesies homolognya dari database $\mathrm{NCBI}$, namun jarak evolusi Y.40.6 berjauhan dengan spesies homolognya dan lebih mendekati $B$. cereus strain DHM5-1 yang digunakan sebagai ingroup (Gambar 3). Streptomyces albidoflavus yang digunakan sebagai outgroup berada di luar cluster Bacillus.

Penelitian sebelumnya telah banyak melaporkan bahwa kelompok Bacillus yang diperoleh dari lingkungan akuatik merupakan salah satu spesies potensial penghasil enzim selulase. Azadian et al. (2016) melaporkan bahwa $B$. licheniformis yang diisolasi dari sumber air panas memiliki aktivitas spesifik 412,32 U/mg. B. megaterium yang diisolasi dari laut juga mampu menghasilkan selulase yang toleran kadar garam tinggi (Shobharani et al. 2013). Selain itu, $B$. cereus yang diisolasi dari usus ikan juga mampu menghasilkan selulase yang berpotensi untuk sakarifikasi selulosa (Tabssum et al. 2018). Bakteri laut Gram positif penghasil selulase lainnya telah berhasil diisolasi oleh Fatokun et al. (2016), yaitu Streptomyces albidoflavus yang bersumber dari sedimen laut juga

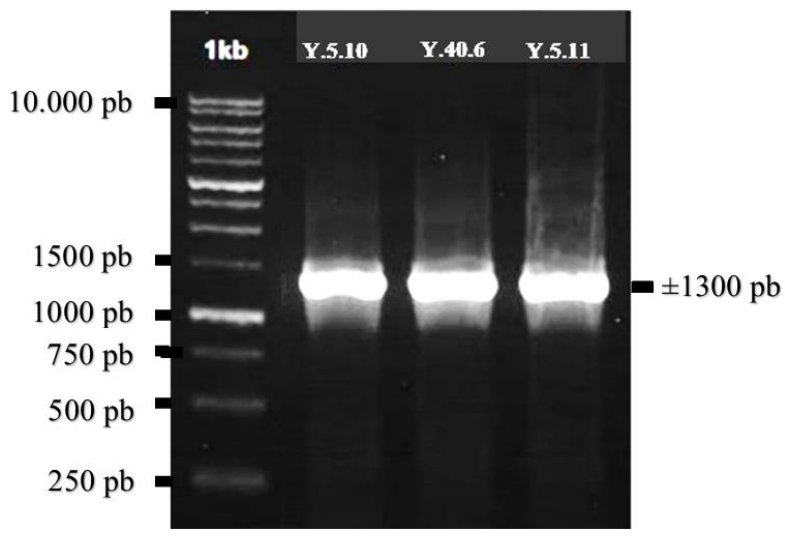

Gambar 2 Elektroforesis gel agarosa 1\% gen 16S rRNA isolat Y.5.10, Y.5.11, dan Y.40.6. $1 \mathrm{~kb}: 1 \mathrm{~kb}$ ladder DNA marker.

Tabel 3 Aktivitas spesifik enzim selulase dari tiga isolat bakteri terbaik yang diisolasi dari spons

\begin{tabular}{cccc}
\hline Kode isolat & $\begin{array}{c}\text { Aktivitas } \\
\text { enzim }(\mathrm{U} / \mathrm{mL})\end{array}$ & $\begin{array}{c}\text { Kadar } \\
\text { protein } \\
(\mathrm{mg} / \mathrm{mL})\end{array}$ & $\begin{array}{c}\text { Aktivitas } \\
\text { spesifik } \\
(\mathrm{U} / \mathrm{mg})\end{array}$ \\
\hline Kontrol & 0 & 0 & - \\
Y.5.10 & 0,0053 & 0,0264 & 0,2025 \\
Y.5.11 & 0,0083 & 0,0407 & 0,2043 \\
Y.40.6 & 0,0124 & 0,0365 & 0,3391 \\
\hline Keterangan:U (unit: Satu unit aktivitas enzim selulase \\
didefinisikan sebagai jumlah enzim yang \\
dibutuhkan untuk melepas 1 mikromol glukosa \\
per menit).
\end{tabular}


Tabel 4 Identitas tiga isolat bakteri selulolitik terbaik yang diisolasi dari spons berdasarkan gen 16S rRNA

\begin{tabular}{rlccccc}
\hline $\begin{array}{l}\text { Kode } \\
\text { isolat }\end{array}$ & \multicolumn{1}{c}{ Homologi } & $\begin{array}{l}\text { Max score/ } \\
\text { Total score }\end{array}$ & E-value & Kemiripan & $\begin{array}{l}\text { Query } \\
\text { cover }\end{array}$ & No. akses \\
\hline Y.5.10 & $\begin{array}{l}\text { Bacillus sp. GNTEW- } \\
13-1\end{array}$ & $1783 / 1783$ & 0 & $99,90 \%$ & $99 \%$ & KM259620.1 \\
Y.5.11 & $\begin{array}{l}\text { Bacillus subtilis strain } \\
\text { BAB-7051 }\end{array}$ & $2170 / 2170$ & 0 & $99,42 \%$ & $100 \%$ & MF319815.1 \\
Bacillus cereus strain & $1779 / 1779$ & 0 & $99,90 \%$ & $99 \%$ & HM104649.1 \\
Y.40.6 & 45-5 & & & & & \\
\hline
\end{tabular}

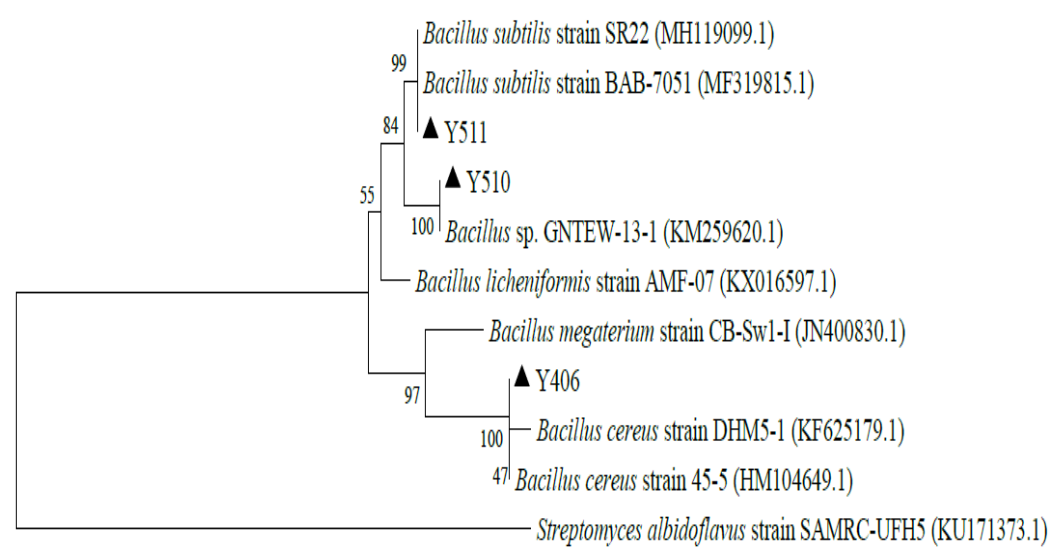

0.02

Gambar 3 Pohon filogenetik hubungan kekerabatan tiga isolat bakteri selulolitik potensial Y5.11, Y5.10, dan Y40.6 dengan spesies homolog berdasarkan sekuens gen 16S rRNA.

yang digunakan sebagai outgroup dalam penelitian ini dan berada di luar cluster Bacillus. Berdasarkan hasilhasil penelitian tersebut, maka tiga isolat bakteri selulolitik terbaik yang diperoleh, berpotensi untuk dikembangkan lebih lanjut sebagai penghasil selulase mikrob.

\section{KESIMPULAN}

Sebanyak 38 isolat bakteri yang berasosiasi dengan spons berhasil diisolasi dan 14 (37\%) isolat di antaranya menghasilkan enzim selulase dengan indeks selulolitik yang bervariasi $(0,31-1,63)$. Aktivitas enzim selulase terbaik ditunjukkan oleh tiga isolat, yakni Y.5.10, Y.5.11, dan Y.40.6 yang secara berturutturut adalah $0,0053 \mathrm{U} / \mathrm{mL}, 0,0083 \mathrm{U} / \mathrm{mL}$, dan 0,0124 $\mathrm{U} / \mathrm{mL}$. Berdasarkan gen $16 \mathrm{~S}$ rRNA, tiga isolat tersebut teridentifikasi sebagai Bacillus spp. dengan spesies dan strain yang berbeda-beda.

\section{UCAPAN TERIMA KASIH}

Sebagian penelitian ini didanai oleh Kementerian Riset, Teknologi, dan Pendidikan Tinggi tahun 2019 dan sebagian dari Kementerian Riset dan Teknologi/Badan Riset dan Inovasi Nasional (BRIN) melalui Penelitian Dasar tahun 2021 kepada ATW. Untuk itu penulis mengucapkan terima kasih atas pendanaan ini.

\section{DAFTAR PUSTAKA}

Ali N, Ting Z, Khan YH, Athar MA, Long M. 2014. Enzymatic hydrolysis of cellulosic biomass for the production of biofuels, a review. International Journal of Engineering and Technical Research. 2(12): 89-96.

Azadian F, Badoei-dalfard A, Namaki-Shoushtari A, Hassanshahian M. 2016. Purification and biochemical properties of a thermostable, haloalkaline cellulase from Bacillus licheniformis AMF-07 and its application for hydrolysis of different cellulosic substrates to bioethanol production. Miriam Budiardjo Resource Center. 5(3): 143-155.

Bradford MM. 1976. A rapid and sensitive method for the quantitation of microgram quantities of protein utilizing the principle of protein-dye binding. Analytical Biochemistry. 72: 248-254. https://doi.org/10.1016/ 0003-2697(76)90527-3

dos Santos YQ, de Veras BO, de França AFJ, GorlachLira K, Velasques J, Migliolo L, dos Santos EA. 2018. A new salt-tolerant thermostable cellulase from a marine Bacillus sp. strain. Journal of Microbiology Biotechnology. 28(7): 1078-1085. https://doi.org/10.4014/jmb.1802.02037

Fatokun EN, Nwodo UU, Okoh Al. 2016. Classical optimization of cellulase and xylanase production by a marine Streptomyces species. Applied Sciences 
6(10): 286-299. https://doi.org/10.3390/ app6100286

Gaur R, Tiwari S. 2015. Isolation, production, purification and characterization of an organicsolvent-thermostable alkalophilic cellulase from Bacillus vallismortis RG-07. BMC Biotechnology. 5:19. https://doi.org/10.1186/s12896-015-0129-9

Gohel HR, Contractor CN, Ghosh SK, Braganza VJ. 2014. A comparative study of various staining techniques for determination of extra cellular cellulase activity on carboxy methyl cellulose (CMC) agar plates. International Journal of Current Microbiology and Applied Sciences. 3(5): 261-266.

Kuhad RC, Gupta R, Singh A. 2011. Microbial cellulases and their industrial applications. Enzyme Research 2011: ID280696. https://doi.org/ $10.4061 / 2011 / 280696$

Lavrov AI, Kosevich IA. 2014. Sponge cell reaggregation: Mechanisms and dynamics of the process. Russian Journal of Developmental Biology. 45(4): 205-223. https://doi.org/10.1134/ S1062360414040067

Maharsiwi W, Astuti RI, Meryandini A, Wahyudi AT. 2020. Screening and characterization of spongeassociated bacteria from Seribu Island, Indonesia producing cellulase and laccase enzymes. Biodiversitas. 21(3): 975-981. https://doi.org/ 10.13057/biodiv/d210317

Marchesi JR, Sato T, Weightman AJ, Martin TA, Fry JC, Hiom SJ, Wade WG. 1998. Design and evaluation of useful bacterium-specific PCR primers that amplify genes coding for bacterial 16S rRNA. Applied and Environmental Microbiology Journal. 64(2): 795-799. https://doi.org/10.1128/AEM.64. 2.795-799.1998

Miller GL. 1959. Use of dinitrosalicylic acid reagent for determination of reducing sugar. Analytical Chemistry. 31(3): 426-428. https://doi.org/10.1021/ ac60147a030

Prastya ME, Astuti RI, Batubara I, Wahyudi AT. 2019. Antioxidant, antiglycation and in vivo antiaging effects of metabolite extracts from marine spongeassociated bacteria. Indian Journal of Pharmaceutical Sciences. 81(2): 344-353. https:// doi.org/10.36468/pharmaceutical-sciences.516

Rini AF, Yuhana M, Wahyudi AT. 2017. Potensi bakteri penghasil senyawa bioaktif yang berasosiasi dengan spons sebagai biokontrol penyakit vibriosis pada udang. Jurnal Akuakultur Indonesia. 16(1): 41-50. https://doi.org/10.19027/jai.16.1.41-50
Safari WF, Chasanah E, Wahyudi AT. 2016. Antibacterial and anticancer activities of marine bacterial extracts and detection of genes for bioactive compounds synthesis. International Journal of Pharmacy and Pharmaceutical Sciences 8(2): $\quad 55-59$. https://innovareacademics.in/ journals/index.php/ijpps/article/view/9778.

Santos-Gandelman JF, Giambiagi-deMarval M, Oelemann WMR, Laport MS. 2014. Biotechnological potential of sponge-associated bacteria. Current Pharmaceutical Biotechnology. 15: 143-155. https://doi.org/10.2174/13892010 15666140711115033

Shobharani P, Yogesh D, Halami PM, Sachindra NM. 2013. Potential of cellulase from Bacillus megaterium for hydrolysis of Sargassum. Journal of Aquatic Food Product Technology. 22: 520-535. https://doi.org/10.1080/10498850.2012.670836

Tabssum F, Irfan M, Shakir HA, Qazi JI. 2018. RSM based optimization of nutritional conditions for cellulase mediated saccharification by Bacillus cereus. Journal of Biological Engineering. 12(1): 716. https://doi.org/10.1186/s13036-018-0097-4

Thomas TRA, Kavlekar DP, LokaBharathi PA. 2010. Marine drugs from spongemicrobe association-A review. Marine Drugs. 8: 1417-1468. https://doi.org/10.3390/md8041417

Trivedi N, Reddy CRK, Lali AM. 2016. Chapter two marine microbes as a potential source of cellulolytic enzymes. Advances in Food and Nutrition Research. 79: 27-41. https://doi.org/10.1016/ bs.afnr.2016.07.002

Vartoukian SR, Palmer RM, Wade WG. 2010. Strategies for culture of 'unculturable' bacteria. FEMS Microbiology Letters. 309(1): 1-7. https://doi.org/10.1111/j.1574-6968.2010.02000.x

Wahyudi AT, Qatrunnada, Mubarik NR. 2010. Screening and characterization of protease inhibitors from marine bacteria associated with sponge Jaspis sp. HAYATI Journal of Biosciences. 17 (4): 173-178. https://doi.org/10.4308/ hjb.17.4.173

Webster NS, Taylor MW. 2012. Marine sponges and their microbial symbionts: Love and other relationships. Environmental Microbiology. 14(2): 335-346. $\quad$ https://doi.org/10.1111/j.14622920.2011.02460.x

Webster NS, Thomas T. 2016. The sponge hologenome. ASM. 7(2): 1-14. https://doi.org/ 10.1128/mBio.00135-16 